\title{
CALCAREOUS NANNOFOSSIL BIOSTRATIGRAPHY OF THE BASAL PART OF VIGLA SHALE MEMBER (IONIAN ZONE) IN ITHAKI ISLAND; PRELIMINARY RESULTS*
}

\author{
M.V. Triantaphyllou' , V. Karakitsios ${ }^{1} \&$ D. Mantzouka' \\ ${ }^{1}$ National \& Kapodistrian University of Athens, Faculty of Geology \& Geoenvironment, Department \\ of Historical Geology-Paleontology, Panepistimiopolis 15784, Athens, Greece, \\ mtriant@geol.uoa.gr, vkarak@geol.uoa.gr
}

\begin{abstract}
The calcareous nannofossil biostratigraphy, performed at the basal part of the Vigla Shale Member (Frygano section, Ithaki Island), permits its biostratigraphic correlation with the uppermost part of BC21 biozone (Bown et al., 1998) and the upper part of NC7 biozone (Roth, 1978), which chronostratigraphically point to Late Aptian. This result reinforces the hypothesis that the deposition of Vigla Shales is isochronous in the lonian zone.
\end{abstract}

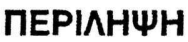

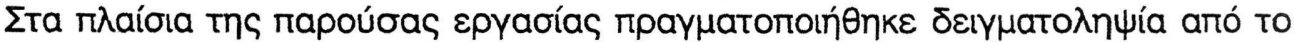

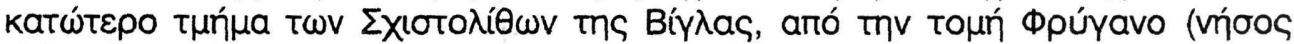

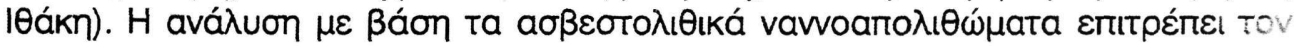

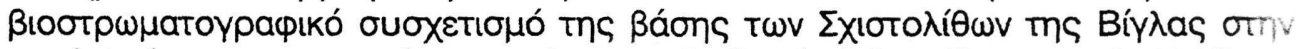

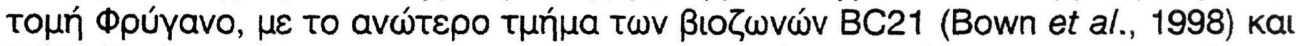

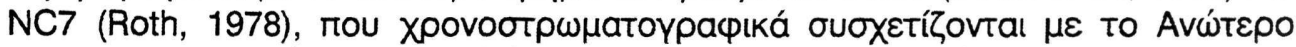

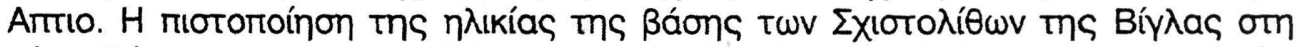

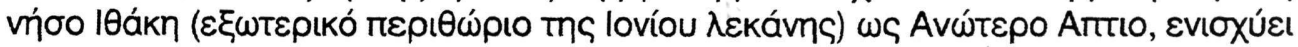

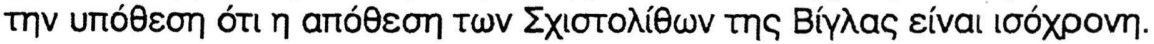

\section{Introduction.}

\section{Geological Setting}

Ithaki Island mainly consists of Ionian zone sediments, represented according to IGME map (1991) by Upper Triassic-Middle Lias Pantokrator limestones, Toarcian "Ammonitico Rosso", Doggerian cherts, limestones and sha- les, Vigla limestones, Albian-Touronian cherts (corresponding to Vigla Shale Member), Senonian ciastic limestones, Paleocene Exene sublithographic limestones a ilysch.

The stratigraphy of the lonian zone (externai Hellenides, western Greece) exhibits three distinct sequences (Kara-

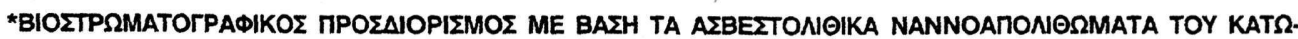

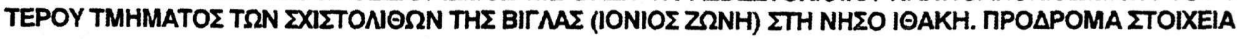

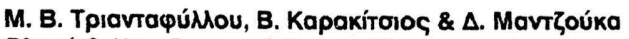

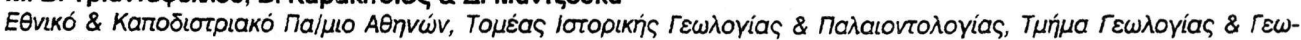

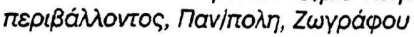


kitsios, 1992, 1995); a prerift, a synrift and a postrift sequence. The latter one consists of the Vigla limestones and overlying Alpine formations and is defined by an Early Berriasian breakup at the base. The postrift sequence continued till the end of the Eocene, followed by the deposition of flysch sediments (Karakitsios 1992, 1995; Sotiropoulos et al. 2003).

The Vigla limestone Formation comprises a thick succession of thin-layered, sublithographic pelagic limestones with frequent cherty beds. The radiolarian fauna from the lowermost part of Vigla limestones have shown that these strata were deposited after the Middle Tithonian (Karakitsios et al., 1988). Karakitsios \& Koletti (1992) concluded that the beginning of Vigla limestone deposition is isochronous in the Ionian zone and starts in Early Berriasian. In their upper part, Vigla limestones contain a series of organic matter-rich marlstones and shales interbedded in limestone and chert beds; the Vigla Shale Member. This member corresponds to the Albian-Cenomanian "Upper Siliceous Zone" of IGRS-IFP (1966). More recently Karakitsios et al. (2004) dated the Vigla Shales at Gotzikas area (NW Epirus) as Aptian-Touronian.

The main scope of the present study is to give further evidence concerning the biostratigraphic correlation of the Vigla Shale Member at the westernmost margin of the lonian zone, on the basis of calcareous nannofossil analysis.

\section{Materials And Methods. Description Frygano Section}

We examined the Vigla Shale Member in Frygano section, located at the middle part of Ithaki Island (Fig. 1), along the

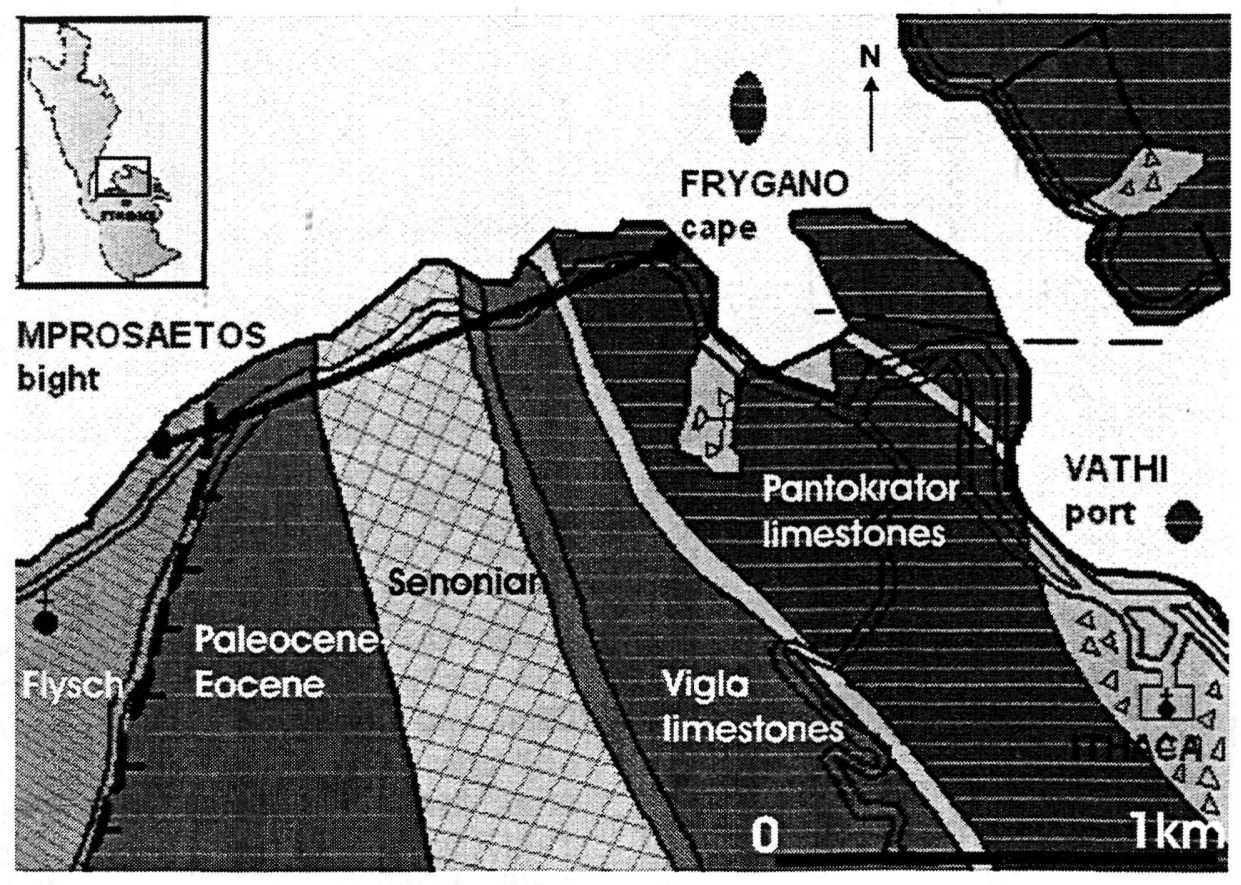

Fig. 1. Location of Frygano section at Ithaki Island and geological map of the area after IGME (1991). 
motorway connecting the city of Ithaki (east) with Mprosaetos bight to the west. It comprises of more than $1 \mathrm{~km}$ of sediments, representing an almost complete stratigraphic column of the Ionian zone (Fig. 2). Thirty six samples

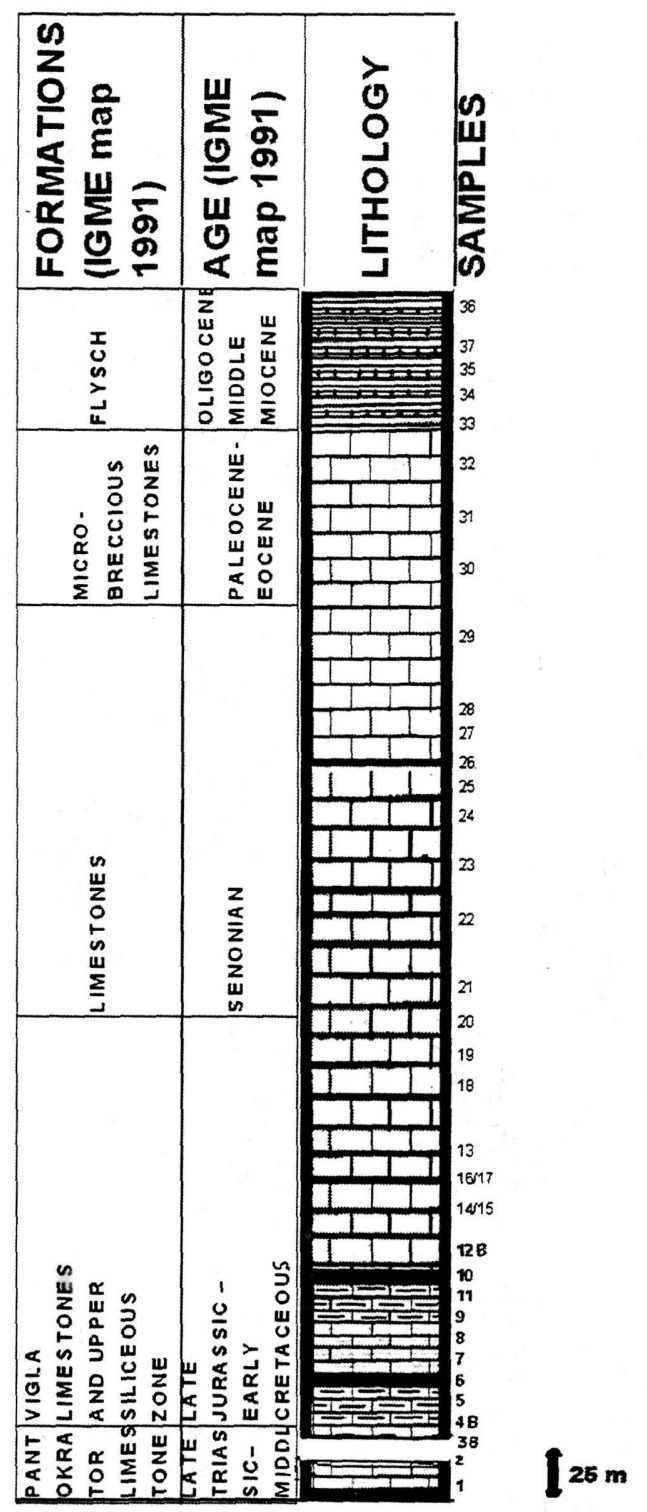

Fig. 2. Lithostratigraphic column of Frygano section. have been collected throughout the section, but in the framework of this study only those coming from the Vigla limestones, and in particular the Vigla Shale member, have been analyzed. The Vigla limestones are represented in Frygano section by more than $100 \mathrm{~m}$ in thickness, white, thin-layered pelagic limestones with chert intercalations. The Vigla Shale Member is represented in the same section by thin-layered marly horizons interbedding the limestone layers (Fig. 3). Smear slides for nannofossil analysis have been prepared with standard techniques and analyzed under light microscope (LM). In order to search thoroughly for the marker species, around 1650 fields of view have been investigated per slide, under 1250x. The taxonomy of the determined calcareous nannofossil species has been based on Perch-Nielsen (1985) and Bown et al. (1998). The nannofossil biostratigraphic results are based on the biozonal schemes of Roth (1978) and Bown et al. (1998).

\section{Calcareous Nannofossil Biostratigraphy}

The analyzed samples show nannofosil abundances which range from rare to abundant; the preservation state is moderate to poor.

The assemblages (Tab. 1) are dominated by:

Rhagodiscus achylostaurion (Hill, 1976) Doeven, 1983, R.gallagheri Rutledge \& Bown (1996), Polypodorhabdus madingleyensis Black, 1971, Retecapsa surirella (Deflandre \& Fert, 1954) Grun in Grun and Allemann, 1975, Flabellites oblongus (Bukry, 1969) Crux in Crux et al., 1982, Helenea chiastia Worsley, 1971, Cyclagelosphaera margerelii Noel, 1965, Watznaueria manivitiae Bukry, 1973, Watznaueria britannica (Stradner, 


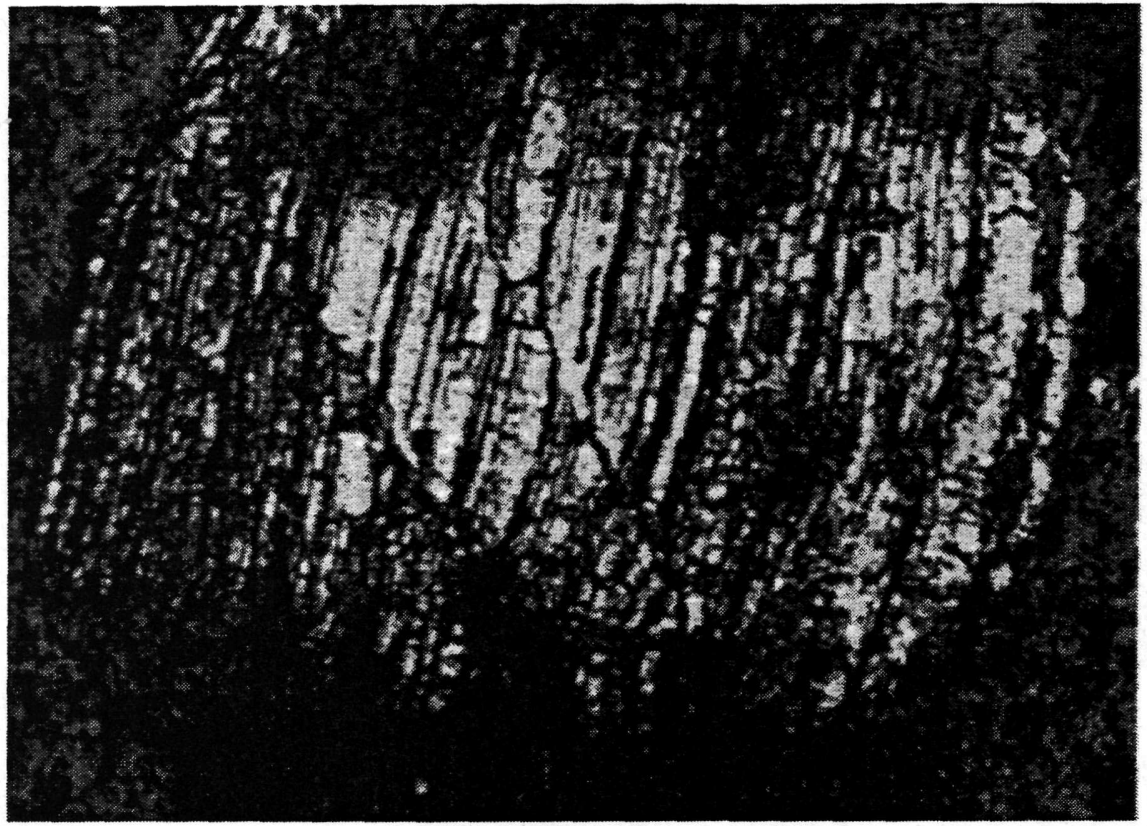

Fig. 3. Outcrop of Vigla Shale Member at Frygano section, Ithaki Island.
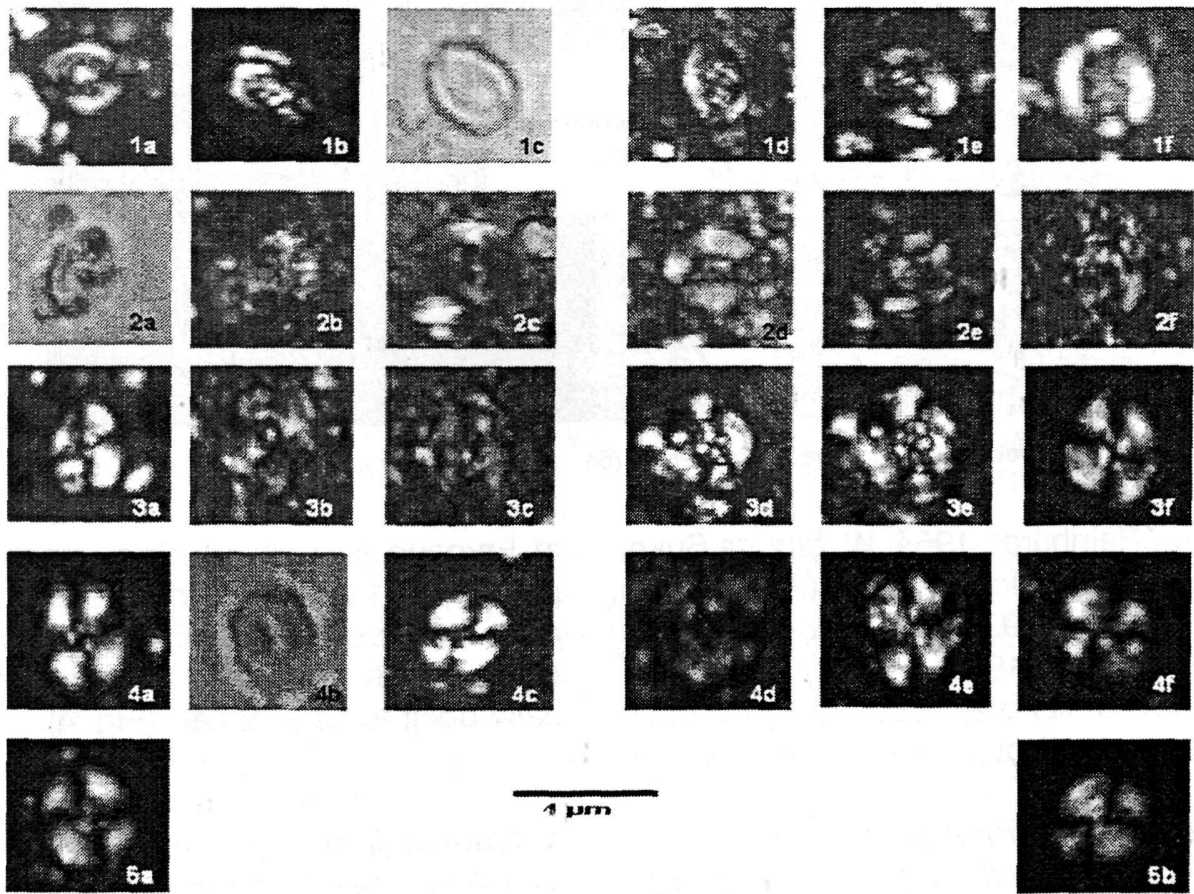

Table 1. Rhagodiscus achylostaurion (1a), R.gallagheri (1b - $f$, 2a), Polypodorhabdus madingleyensis (2b), Retecapsa surirella (2c -e), Flabellites oblongus (2f, 3a - 3c), Helenea chiastia (3d-e), Watznaueria manivitiae (3f), Cyclagelosphaera margerelii $(4 a-b)$, Watznaueria britannica $(4 c-d)$, W. biporta $(4 e-f, 5 a-b)$ 


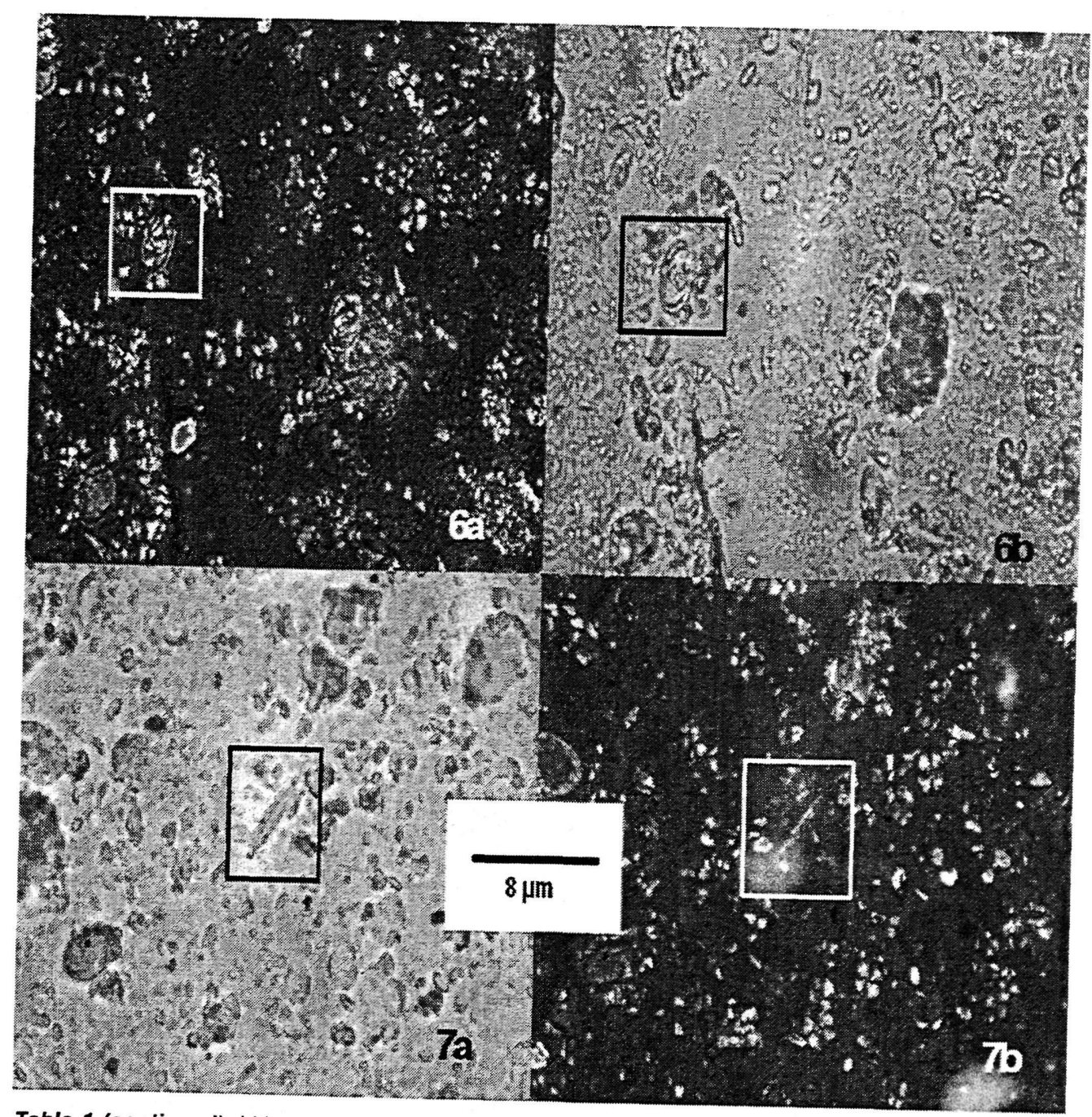

Table 1 (continued). Lithraphidites carniolensis $(6 a-b)$, Zeugrhabdotus embergeri $(7 a-b)$.

1963) Reinhardt, 1964, W. biporta Bukry, 1969, Farhania varolii (Jakubowski, 1986) Varol, 1992, Nannoconus cf. truitti Bronnimann, 1955, Lithraphidites carniolensis Deflandre, 1963, Zeugrhabdotus embergeri (Noel, 1959) Perch-Nielsen, 1984.

The contemporaneous presence of Rhagodiscus achylostaurion, $R$. gallagheri, Nannoconus cf. truitti and Farhania varolii allows the biostratigraphic correlation of the base of Vigla Shale Member at Frygano section with the uppermost part of BC21 biozone (Bown et al., 1998) and the upper part of NC7 biozone (Roth, 1978), which chronostratigraphically point to Late Aptian (Fig. 4).

\section{Conclusions}

The Vigla Shale Member, a siliceous and organic carbon-rich facies, was considered before as Albian-Cenomanian in age (IGRS-IFP, 1966). Recently 


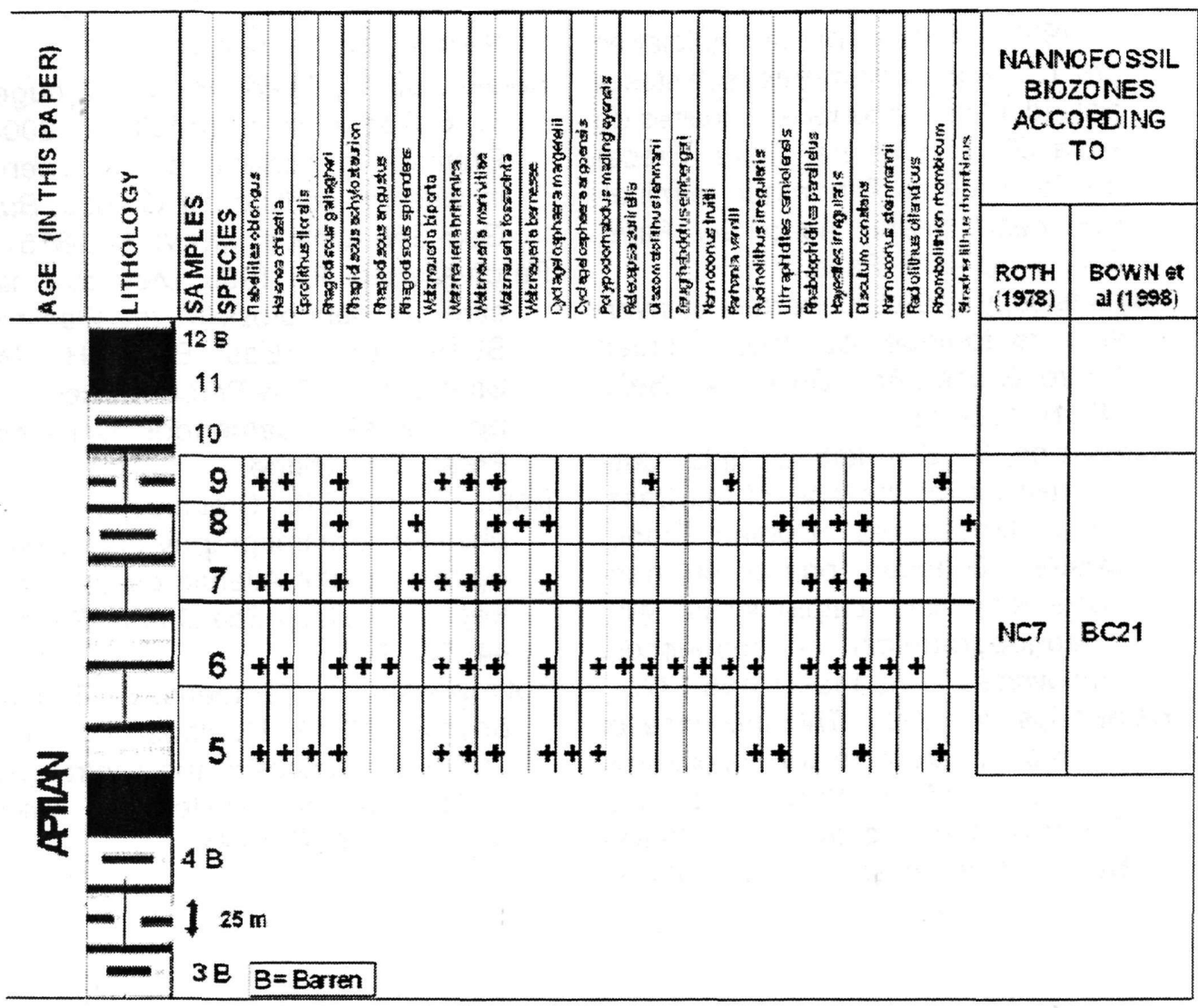

Fig. 4. Calcareous nannofossil species distribution and biostratigraphic correlation of the Vigla Shale Member at Frygano section

Karakitsios et al. (2004) dated the Vigla Shales at Gotzikas area (NW Epirus) as Aptian-Touronian.

The present study performed at the basal part of the Vigla Shale Member (Frygano section, Ithaki Island), permits its biostratigraphic correlation with the uppermost part of BC21 biozone (Bown et al., 1998) and the upper part of NC7 biozone (Roth, 1978), which chronostratigraphically point to Late Aptian. The determined age fits well with previous biostratigraphic data, reinforcing the hypothesis that the deposition of Vigla Shales is isochronous in the Ionian zone.

\section{References}

Bown, P.R., Rutledge, D.G., Crux, J.A., \& Gallagher, L.T., 1998. Lower Cretaceous. In: Calcareous nannofossil biostratigraphy (Ed. Bown, P.R.), pp. 86-131, British Micropaleontological Society Series, Chapman \& Hall/Kluwer Academic Publishers, London.

IGME, 1991. Ithaki-Atokos geological map. Institute of Geology and Mineral Exploration, Athens.

IGRS-IFP, 1966. Etude geologique de l'Epire (Grece nord-occidentale). Ed. Technip, 306 pp., Paris.

Karakitsios, V., Danelian, T., \& de Wever, 
P., 1988. Datations par les radiolaires des calcaires a filaments, schistes a posidonies superieurs et calcaires de Vigla (Zone Ionienne, Epire, Grece) du Callovien au Tithonique terminal. C.R. hebd. Seanc. Acad. Sci. Paris, 306, 2, 367-372, Paris.

Karakitsios, V., 1992. Ouverture et inversion tectonique du basin Ionien (Epire, Grece). Ann. Geol. Pays Hell., 35 (1): 185-318.

Karakitsios, V., \& Koletti, L.,1992. Critical revision of the age of the basal Vigla limestones (Ionian zone, western Greece), based on nannoplankton and calpionellids, with paleogeographical consequences. Knihovnicka ZPN, 14a(1), 165-177.

Karakitsios, V., 1995. The Influence of Preexisting Structure and Halokinesis on Organic Matter Preservation and Thrust System Evolution in the lonian Basin, Northwest Greece. AAPG
Bulletin, 79, (7): 960-980.

Karakitsios, V., Tsikos H., Van Breugel, Y., Bakopoulos, I., Koletti, L., 2004. Cretaceous oceanic anoxic events in western continental Greece. Bull. Geol.Soc.Greece, XXXVI: 846-855.

Perch-Nielsen, K., 1985. Mesozoic calcareous nannofossils. In: Plankton Stratigraphy (Eds Bolli, H. M., Saunders, J. B. \& Perch-Nielsen, K.), pp. 329-426, Cambridge University Press, Cambridge.

Roth, P., H., 1978. Cretaceous nannoplankton biostratigraphy and oceanography of the Atlantic ocean. Initial Reports of Deep Sea Drilling Project, 44, 731-760.

Sotiropoulos, S., Kamberis, E., Triantaphyllou, M., \& Doutsos, T., 2003, Thrust sequences in the central part of the External Hellenides. Geol. Mag., 140 (6):661-668. 